\title{
Increased levels of anti-dsDNA antibodies in immune complexes before treatment with belimumab associate with clinical response in patients with systemic lupus erythematosus
}

Azita Sohrabian ${ }^{1 \dagger}$, Ioannis Parodis ${ }^{2,3 \dagger}$, Nellie Carlströmer-Berthén ${ }^{1}$, Martina Frodlund ${ }^{4}$, Andreas Jönsen ${ }^{5}$, Agneta Zickert ${ }^{2,3}$, Christopher Sjöwall ${ }^{4}$, Anders A. Bengtsson ${ }^{5}$, Iva Gunnarsson ${ }^{2,3 \dagger}$ and Johan Rönnelid ${ }^{1 * \dagger}$ (D)

\begin{abstract}
Introduction: Immune complexes are of importance in systemic lupus erythematosus pathogenesis, and autoantibodies are believed to participate in immune complex formation. Quantification of autoantibody levels in circulating IC might be of prognostic value.

Methods: A C1q-binding-eluting technique was applied to purify immune complexes from 55 belimumab-treated systemic lupus erythematosus patients during a 24-month follow-up. Autoantibodies in serum and in solubilized immune complexes were quantified using addressable laser bead immunoassay. We investigated whether levels of autoantibodies in immune complexes associate with disease activity and response to belimumab treatment.

Results: High baseline anti-double-stranded DNA and anti-histone levels in immune complexes associated with attainment of zero scores in clinical systemic lupus erythematosus disease activity index 2000 during the 24-month follow-up ( $p=0.003$ and $p=0.048$, respectively). Low complement levels associated with high serum anti-doublestranded DNA and anti-ribosomal P levels ( $p=0.003$ and $p=0.008$, respectively) and high anti-double-stranded DNA $(p=0.002)$ but not anti-ribosomal P levels in immune complexes. Anti-SSA/SSB serum levels were lower in patients attaining lupus low disease activity state at month 6; these associations were stronger for corresponding immune complex levels. Serum levels of most autoantibodies had declined at month 3, whereas autoantibody levels in immune complexes, except for anti-double-stranded DNA, showed a more gradual decline over 1-2 years. Serum anti-double-stranded DNA levels decreased in all patients irrespective of systemic lupus erythematosus disease activity index 2000=0 attainment, whereas immune complex levels decreased only in achievers.

(Continued on next page)
\end{abstract}

\footnotetext{
* Correspondence: johan.ronnelid@igp.uu.se

${ }^{\dagger}$ Azita Sohrabian and loannis Parodis contributed equally as first authors.

${ }^{+}$Iva Gunnarsson and Johan Rönnelid contributed equally as senior authors.

1 Department of Immunology, Genetics and Pathology, Uppsala University,

Rudbeck Laboratory, SE-75185 Uppsala, Sweden

Full list of author information is available at the end of the article
}

(c) The Author(s). 2019 Open Access This article is distributed under the terms of the Creative Commons Attribution 4.0 International License (http://creativecommons.org/licenses/by/4.0/), which permits unrestricted use, distribution, and reproduction in any medium, provided you give appropriate credit to the original author(s) and the source, provide a link to the Creative Commons license, and indicate if changes were made. The Creative Commons Public Domain Dedication waiver (http://creativecommons.org/publicdomain/zero/1.0/) applies to the data made available in this article, unless otherwise stated. 


\begin{abstract}
(Continued from previous page)
Conclusion: Immune complex levels of autoantibodies against double-stranded DNA and the SSA/SSB complex show more specific associations with treatment outcome compared with serum levels in belimumab-treated systemic lupus erythematosus patients. Characterization of autoantibody content in circulating immune complexes could prove useful in treatment evaluation in systemic lupus erythematosus and other immune complex-associated diseases.
\end{abstract}

Keywords: Systemic lupus erythematosus, Belimumab, Anti-nuclear autoantibodies, Anti-double-stranded DNA, Immune complexes, Therapy response

\section{Introduction}

Systemic lupus erythematosus (SLE) is an autoimmune disease with heterogeneous expression, ranging from mild symptoms limited to the skin and joints to more severe manifestations such as renal involvement, severe cytopenia, or central nervous system disease [1]. SLE is characterized by a loss of immunologic tolerance, excessive formation of circulating anti-nuclear antibodies (ANA), and inflammatory involvement of multiple organs [1-5]. Autoantibodies are often presumed to participate in pathogenesis via formation of circulating and tissue-bound immune complexes (IC) [6-11].

Antibodies that recognize and bind to double-stranded (ds)DNA are serological hallmarks of both classification and disease activity in SLE [12]. The molecular characteristics of anti-dsDNA are heterogenous, with diverse relation to disease activity and severity. High-avidity anti-dsDNA antibodies are believed to be actively involved in the pathogenesis of lupus nephritis; however, low-avidity antibodies are most frequently associated with cerebral involvement [13-16]. Many SLE patients with a clinically quiescent disease may still show significant levels of anti-dsDNA in the circulation, suggesting that not all anti-dsDNA autoantibodies are pathogenic [17-21]. Pathogenicity is associated to the ability to activate complement, engage $\mathrm{Fc}$ receptors, and exert coreactivity with non-DNA antigens [22, 23].

The mechanisms underlying deposition of IC and autoantibodies and subsequent tissue injury remain controversial. Either in situ binding of circulating autoantibodies to autoantigens planted in tissues $[8,24]$ or deposition of pre-formed circulating IC in tissues, notably mesangial matrix of the kidney $[6,10]$, may lead to classical complement activation and eventually tissue damage and organ failure. If specific autoantibodies like anti-dsDNA participate in the formation of circulating IC which later sequester in target organs, then quantification of the autoantibodies residing in circulating IC might be a valuable prognostic biomarker.

Belimumab, a recombinant human $\operatorname{IgG}_{1}-\lambda$ monoclonal antibody against B lymphocyte stimulator (BLyS, also known as BAFF), is a biologic agent approved for the treatment of patients with active SLE despite ongoing standard of care therapy [25-27]. Treatment with belimumab decrease circulating anti-dsDNA levels [25, $28,29]$. There are to our knowledge no published studies on changes in levels of other autoantibodies or the role of IC or autoantibodies in IC in belimumab-treated SLE patients.

Several studies have reported difficulties in identification and quantification of autoantibodies in circulating IC. As long as antigen-binding sites are occupied in IC, specific antibodies will not bind in immunoassays. AntidsDNA in IC might be physically masked by antiU1RNP or other antigen-antibody systems constituting major components of IC [30-32]. We have developed a bead-based assay where isolation of IC on magnetic beads is followed by a two-step elution procedure, during which IC are freed from the beads and (auto)antibodies are freed from corresponding (auto)antigens. This technique allows the quantification of multiple autoantibodies in circulating IC as we recently did in a work evaluating individual anti-citrullinated peptide antibodies (ACPA) in IC from patients with rheumatoid arthritis [33]. Here, we applied this assay to samples from SLE patients treated with belimumab in a real-life clinical setting, in order to evaluate whether quantification of autoantibodies in IC yields additional information in terms of disease activity and treatment response compared to conventional serum autoantibody measurements [29].

\section{Materials and methods}

\section{Study patients and controls}

A total of 55 patients with moderately active SLE despite standard of care therapy from three tertiary referral centers in Sweden at the Karolinska $(n=30)$, Lund $(n=18)$, and Linköping $(n=7)$ university hospitals, who initiated belimumab treatment were enrolled in this prospective observational study. All patients fulfilled the 1982 American College of Rheumatology and/or the Systemic Lupus International Collaborating Clinics (SLICC) classification criteria of SLE [34, 35]. After initiation of belimumab therapy, the patients were followed for a maximum of 24 months. Serum samples were obtained from $55,41,35,30$, and 22 patients at baseline after 3, 6, 
12 , and 24 months, respectively, and stored at $-80{ }^{\circ} \mathrm{C}$ until analysis. A more detailed description of the study criteria has been published previously [29]. Patient baseline characteristics are presented in Table 1.

Surveillance items included the SLE disease activity index 2000 (SLEDAI-2K) [36]. We used serum antidsDNA data centrally analyzed in Uppsala for this study to calculate SLEDAI-2 K at all time points. Treatment response was assessed using three different definitions: clinical (c)SLEDAI-2K=0 (a modification of SLEDAI-2K where complement levels and anti-dsDNA positivity are excluded) [37], attainment of Lupus Low Disease Activity State (LLDAS) [38], and the SLE responder index 4 (SRI4) $[25,26,28]$. Details were described previously [29].

Table 1 Baseline characteristics based on the 55 investigated SLE patients

\begin{tabular}{|c|c|}
\hline \multicolumn{2}{|l|}{ Characteristic } \\
\hline Female participants, $n(\%)$ & $50(90.9)$ \\
\hline \multicolumn{2}{|l|}{ Ethnicity } \\
\hline Caucasian, $n(\%)$ & $52(94.5)$ \\
\hline African/African American, $n(\%)$ & $3(5.5)$ \\
\hline Age (years), median (IQR) & $41.2(30.6-50.4)$ \\
\hline SLE disease duration (years), median (IQR) & $7.8(4.3-14.2)$ \\
\hline SLEDAI-2K, median (IQR) & $8.0(4.0-14.0)$ \\
\hline C3 (g/L), median (IQR) & $0.81(0.62-1.02)$ \\
\hline C4 (g/L), median (IQR) & $0.11(0.06-0.19)$ \\
\hline $\begin{array}{l}\text { Number of DMARDs tested until } \\
\text { baseline*, median (IQR) }\end{array}$ & $2(1-3)$ \\
\hline $\begin{array}{l}\text { Number of DMARDs at } \\
\text { baseline }^{*} \text {, median (IQR) }\end{array}$ & $1(0-1)$ \\
\hline Azathioprine, $n(\%)$ & $18(32.7)$ \\
\hline Mycophenolate mofetil/sodium ${ }^{\dagger}, n(\%)$ & $10(18.2)$ \\
\hline Methotrexate, $n(\%)$ & $8(14.5)$ \\
\hline Cyclosporine, $n(\%)$ & $2(3.6)$ \\
\hline Antimalarial agents at baseline, $n(\%)$ & $41(74.5)$ \\
\hline $\begin{array}{l}\text { Prednisone equivalent dose at baseline } \\
\text { (mg/day), median (IQR) }\end{array}$ & $10.0(8.4-12.9)$ \\
\hline \multicolumn{2}{|l|}{ Reason for belimumab } \\
\hline Mucocutaneous manifestations, $n(\%)$ & $26(47.3)$ \\
\hline Musculoskeletal manifestations, $n(\%)$ & $25(45.5)$ \\
\hline Hematological manifestations, $n(\%)$ & $10(18.2)$ \\
\hline Lupus nephritis, n (\%) & $7(12.7)$ \\
\hline Neuropsychiatric SLE, n (\%) & $4(7.3)$ \\
\hline Serositis, $n(\%)$ & $3(5.5)$ \\
\hline Constitutional symptoms ${ }^{\#}, n(\%)$ & $2(3.6)$ \\
\hline
\end{tabular}

*Excluding antimalarial agents

${ }^{+}$Mycophenolate mofetil $(n=9)$ and mycophenolate sodium $(n=1)$ "Fatigue

SLE systemic lupus erythematosus, SLEDAl-2K systemic lupus erythematosus disease activity index 2000, DMARDs disease-modifying antirheumatic drugs, $I Q R$ interquartile range
As method controls, sera from 20 healthy blood donors from Uppsala University Hospital were investigated for autoantibodies in sera and IC.

Written informed consent was obtained from all patients, and oral consent from the blood donor controls. The study was performed in compliance with the Helsinki Declaration, and the study protocol was approved by the regional ethics review boards in Stockholm, Lund, Linköping, and Uppsala.

\section{Capturing and isolation of circulating IC}

Purification of IC from sera was conducted according to a previously described technique established in our laboratory [33]. In brief, purified human C1q (Quidel, San Diego, CA, USA) was attached to magnetic tosylactivated microparticles (Dynabeads ${ }^{\bullet}$ M-280; Life Technologies, Carlsbad, CA, USA) according to recommendations by the manufacturer for activation of amine groups. Ten microliters of $\mathrm{C} 1 \mathrm{q}$ beads was incubated with $10 \mu \mathrm{L}$ serum and $30 \mu \mathrm{L}$ PBS- $0.05 \%$ Tween-1\% BSA for $1.5 \mathrm{~h}$ on a microplate shaker $(600 \mathrm{rpm})$ at $37^{\circ} \mathrm{C}$. The $\mathrm{C} 1 \mathrm{q}$-bound $\mathrm{IC}$ were sequentially eluted from $\mathrm{C} 1 \mathrm{q}$ beads in two sequential steps utilizing $50 \mu \mathrm{L} 0.1 \mathrm{M}$ glycine$\mathrm{HCl}$, pH 2.5 followed by $100 \mu \mathrm{L}$ freshly prepared $25 \%$ methanol, $\mathrm{pH}$ 11.5. The second elution step has previously been shown to allow freeing of antibodies from corresponding antigen with preservation of antigen specificity [32]. IC eluates that were not assayed the same day were stored at $-80^{\circ} \mathrm{C}$. A full description and validation of the method was published recently [33].

\section{Autoantibody detection}

The levels of antibodies against nuclear antigens (dsDNA, histone, ribosomal P antigen, PCNA, SSARo52, SSA-Ro60, SSB-La, Sm, U1RNP, and the SmU1RNP complex) in serum and in solubilized IC were determined with addressable laser bead immunoassay (ALBIA) applying Connective Profile FIDIS ${ }^{\text {тм }}$ (Theradiag, Marne La Vallee, France) and according to descriptions by the manufacturer, with a minor modification in the acquisition of digital data from the ALBIA equipment to obtain readouts in the low measurement range for IC level quantification. IC eluates were diluted corresponding to dilution of the initial serum and incubated with fluorescent-labeled microsphere reagent for $1 \mathrm{~h}$ on a shaker at RT. Antibody specificities were detected utilizing a phycoerythrin-labeled anti-human IgG conjugate. The levels of antibodies in serum and corresponding IC fractions were expressed in arbitrary units per millilter $(\mathrm{AU} / \mathrm{mL})$ except for anti-dsDNA that was expressed in international units per millilter $(\mathrm{IU} / \mathrm{mL})$. Data were evaluated using Solinium software (Theradiag).

Serum concentrations of total amounts of C1q-binding circulating IC (CIC) were measured by Quanta Lite ${ }^{\circ}$ 
ELISA (INOVA Diagnostics, San Diego, CA, USA), in accordance with instructions by the manufacturer. Ageand sex-matched population-based non-SLE controls from the Karolinska SLE cohort $(n=316)$ served as CIC controls.

Total immunoglobulin G (IgG) in serum and IC were determined using an in-house ELISA, also used in earlier studies [32, 39]. Samples were diluted with PBS-Tween and incubated with solid phase goat anti-human IgG (purified $\mathrm{F}\left(\mathrm{ab}^{\prime}\right) 2, \mathrm{Fc}$ s specific 109-006-098, Jackson IR, USA). The bound IgG was identified using alkalinephosphatase-conjugated goat anti-human IgG (purified $\mathrm{F}\left(\mathrm{ab}^{\prime}\right) 2$, Fcy specific 109-056-098, Jackson). Total IgG concentrations were determined using a serially diluted serum with known immunoglobulin concentration as standard.

Complement factors C3 (reference range 0.67-1.29 g/ $\mathrm{L})$ and $\mathrm{C} 4 \quad(0.13-0.32 \mathrm{~g} / \mathrm{L})$ were determined using nephelometry.

\section{Statistical analyses}

The non-parametric Mann-Whitney $U$ test was employed to compare the levels of antibodies with regard to clinical features. Correlations were assessed using the Spearman's rank correlation coefficient test. For comparisons across groups, the Kruskal Wallis test, and, for pairwise comparisons between baseline and follow-up, the Wilcoxon signed rank test were used.

As our approach of quantitating autoantibodies in solubilized IC is new, we did not know which way to express these data would be most informative in a clinical setting. Therefore, besides measurement of levels in solubilized IC, fractions of specific autoantibodies were also expressed as percentages (\%) of levels in solubilized IC compared with levels obtained with conventional serum measurement in the same samples, or as enrichment of specific autoantibodies in IC where levels in IC and serum had been normalized to the total IgG levels in each compartment, according to the formula

(autoantibody level in IC/total IgG in IC)/

(level of autoantibody in serum/total IgG in serum)

The statistical analyses were performed using JMP version 11 (SAS Institute, Cary, NC, USA). $p$ values $<0.05$ were considered statistically significant.

\section{Results}

\section{Autoantibody levels in serum and IC}

Antibodies against dsDNA, SSA/Ro60, and U1RNP were detected in $65 \%, 54 \%$, and $43 \%$ of the serum samples, whereas the corresponding proportions for other specificities were lower (Fig. 1a). Patterns of autoantibody distributions in solubilized IC (Fig. 1b) followed roughly the ones found in sera, with median IC levels ranging between 0.8 and $13 \%$ of the corresponding serum levels (Fig. 1c). When we normalized IC levels either as percentages compared to serum (Fig. 1c) or as antibody enrichments in IC (Fig. 1d), there were obvious differences in IC accumulation for different autoantibody specificities ( $p<0.0001$ for both approaches). All autoantibodies were enriched in IC compared to sera, with 7.3 to 149 times more autoantibodies in IC after correction for total IgG levels (Fig. 1d). Two autoantibody specificities deviated from remaining specificities: anti-PCNA was more enriched and anti-Sm was less enriched in IC compared to other autoantibodies (Fig. 1c, d; Table 2). Autoantibody levels in 20 healthy control sera and corresponding solubilized IC fractions were substantially lower (Fig. 1e, f).

SLE patients had increased CIC levels compared to controls (Fig. 2g). Most autoantibody levels in sera and solubilized IC except for the anti-SSA/SSB complex correlated to CIC levels, with the highest degree of correlation for anti-dsDNA. When only samples in the positive range were included, correlations only remained significant for anti-dsDNA (Table 3).

\section{Baseline serum and IC autoantibody levels in relation to disease activity}

When patient sera were dichotomized in relation to baseline plasma concentrations of complement proteins C3 and C4 as a measure of serologically active disease, low complement levels were strongly associated with high baseline quantities of anti-dsDNA in both serum $(p=0.003$; Fig. $2 \mathrm{a})$ and IC ( $p=0.002$; Fig. $2 \mathrm{~b})$. A comparable pattern was displayed for levels of anti-ribosomal $\mathrm{P}$ antigen in serum $(p=0.008$; Fig. $2 c)$. IC levels of antiribosomal $\mathrm{P}$ did however not differ between patients with normal and depressed complement levels (Fig. 2d). No corresponding associations with serum levels of other autoantibodies were found. However, high baseline IC levels of anti-histone $(p=0.020)$, anti-Sm $(p=0.043)$, and anti-Sm-U1RNP $(p=0.036)$ associated with low complement levels (data not shown). In relation to measures of disease activity, IC autoantibody levels expressed as percentages compared to serum or as enrichments in IC yielded no or lower significances as compared to crude autoantibody levels in IC.

Serum levels of anti-dsDNA and anti-Sm at inclusion correlated with the full SLEDAI-2 K score; this was not the case for any other autoantibody specificities in serum or in IC. When changes in antibody levels after belimumab treatment were correlated to corresponding changes in SLEDAI-2 K, decreases of serum levels but not IC levels of antibodies against ribosomal $\mathrm{P}$ antigen, PCNA, Sm, U1RNP, and the Sm-U1RNP complex during 2 years of treatment correlated with decreases in 


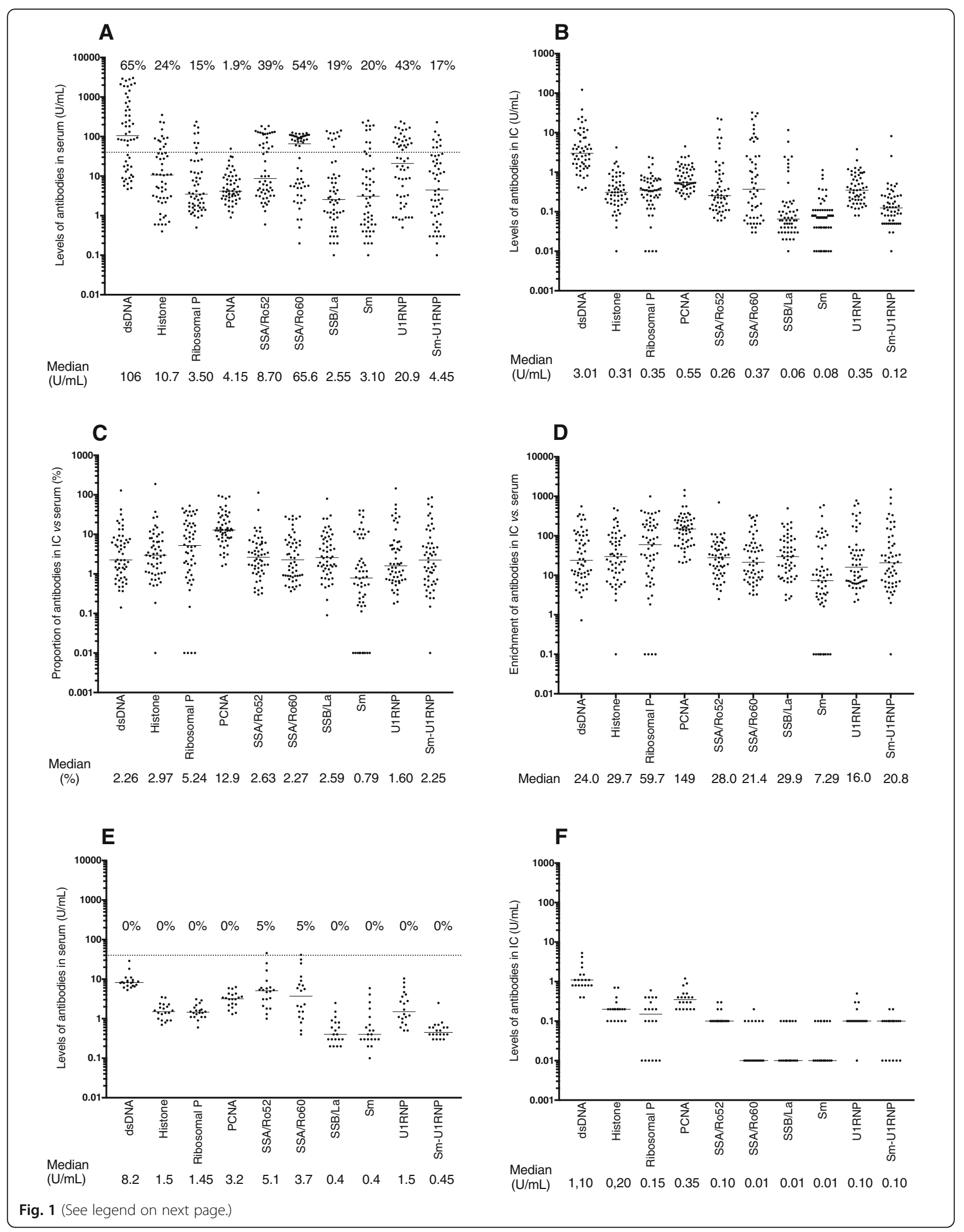


(See figure on previous page.)

Fig. 1 Distribution and levels of autoantibodies in sera $(\mathbf{a}, \mathbf{e})$ and corresponding solubilized IC fractions $(\mathbf{b}, \mathbf{f})$ for patients $(\mathbf{a}, \mathbf{b})$ and 20 healthy controls $(\mathbf{e}, \mathbf{f})$. Levels are presented in arbitrary units $(\mathrm{AU} / \mathrm{mL})$ for all antibodies except for anti-dsDNA, which is presented in international units $(\mathrm{IU} / \mathrm{mL})$. The ratio between autoantibody levels in $\mathrm{IC}$ and conventional measurement in sera among the patients are presented as $\mathbf{c}$ percentage in IC as compared to sera and $\mathbf{d}$ as enrichment after correction for total IgG concentrations in IC and sera, respectively. Median levels are illustrated as horizontal solid lines and the corresponding values are stated below each panel. The horizontal dotted line in $\mathbf{a}$ and $\mathbf{e}$ shows the clinically recommended cutoff values for autoantibodies in serum $(40 \mathrm{U} / \mathrm{mL})$. a, e The prevalence (\%) of specific autoantibodies in serum is presented above each antibody. Values below the measurement ranges are depicted as 0.1 for sera and 0.01 in IC. Ribo P ribosomal P

SLEDAI-2 $\mathrm{K}$ during the same period. A decrease in IC levels of anti-SSA/Ro52 during the first 3 months also correlated with a decrease in SLEDAI-2K (Table 4).

\section{Baseline serum and IC autoantibody levels in relation to clinical response to belimumab}

No association between baseline levels of anti-dsDNA in serum and attainment of cSLEDAI- $2 \mathrm{~K}=0$ during followup was found (Fig. 3a, also seen previously [29]). On the contrary, high baseline levels of anti-dsDNA in IC were clearly associated with cSLEDAI- $2 \mathrm{~K}=0$ achievement during the 24-month follow-up $(p=0.003$; Fig. $3 \mathrm{~b})$. Also, high IC levels of anti-histone showed a similar but weaker association with cSLEDAI-2K=0 through follow- up $(p=0.048)$, again with no association with corresponding serum levels. No association was observed between levels of anti-ribosomal $\mathrm{P}$ antibodies in serum or IC and cSLEDAI-2K=0 during the follow-up period (Fig. 3c, d). Low baseline levels of anti-Sm and anti-SmU1RNP in serum but not in IC were associated with cSLEDAI-2K=0 at month $6(p=0.018$ and 0.040 , respectively), and for anti-Sm-U1RNP also after 3 months of treatment $(p=0.038)$. No other antibodies in serum or IC at baseline exhibited any association with cSLEDAI-2K=0 or SRI-4 at individual time points during the follow-up period, except for an association between low IC levels of anti-PCNA and SRI-4 at 3 months of treatment $(p=0.025)$.

Table 2 Difference in accumulation in immune complexes of different autoantibodies

\begin{tabular}{|c|c|c|c|c|c|c|c|c|c|}
\hline $\begin{array}{l}\text { Percentages in IC compared to } \\
\text { those in sera }\end{array}$ & $\begin{array}{l}\text { dsDNA, } \\
2.26 \%\end{array}$ & $\begin{array}{l}\text { Histone, } \\
2.97 \%\end{array}$ & $\begin{array}{l}\text { Rib } P, \\
5.24 \%\end{array}$ & $\begin{array}{l}\text { PCNA, } \\
12.9 \%\end{array}$ & $\begin{array}{l}\text { SSA/Ro52, } \\
2.63 \%\end{array}$ & $\begin{array}{l}\text { SSA/Ro60, } \\
2.27 \%\end{array}$ & $\begin{array}{l}\text { SSB/La, } \\
2.59 \%\end{array}$ & $\begin{array}{l}\text { Sm, } \\
0.788 \%\end{array}$ & $\begin{array}{l}\text { U1RNP } \\
1.60 \%\end{array}$ \\
\hline Histone, $2.97 \%$ & 0.789 & & & & & & & & \\
\hline Ribosomal P, 5.24\% & 0.103 & 0.115 & & & & & & & \\
\hline PCNA, 12.9\% & $<0.001$ & $<0.001$ & 0.001 & & & & & & \\
\hline SSA/Ro5, 2.63\% & 0.706 & 0.537 & 0.031 & $<0.001$ & & & & & \\
\hline SSA/Ro60, 2.27\% & 0.636 & 0.405 & 0.040 & $<0.001$ & 0.835 & & & & \\
\hline SSB/La, 2.59\% & 0.912 & 0.851 & 0.082 & $<0.001$ & 0.708 & 0.533 & & & \\
\hline Sm, $0.788 \%$ & 0.002 & 0.001 & $<0.001$ & $<0.001$ & $<0.001$ & 0.004 & 0.001 & & \\
\hline U1RNP, 1.60\% & 0.263 & 0.166 & 0.027 & $<0.001$ & 0.330 & 0.507 & 0.196 & 0.009 & \\
\hline Sm-U1RNP, 2.25\% & 0.446 & 0.409 & 0.061 & $<0.001$ & 0.630 & 0.733 & 0.454 & 0.006 & 0.794 \\
\hline Enrichment & $\begin{array}{l}\text { dsDNA, } \\
24.0\end{array}$ & $\begin{array}{l}\text { Histone, } \\
29.7\end{array}$ & $\begin{array}{l}\text { Rib } P, \\
59.7\end{array}$ & $\begin{array}{l}\text { PCNA, } \\
149\end{array}$ & $\begin{array}{l}\text { SSA/Ro, } 52 \\
28.0\end{array}$ & $\begin{array}{l}\text { SSA/Ro,60 } \\
21.4\end{array}$ & $\begin{array}{l}\text { SSB/La, } \\
29.9\end{array}$ & Sm, 7.29 & $\begin{array}{l}\text { U1RNP } \\
16.0\end{array}$ \\
\hline Histone, 29.7 & 0.895 & & & & & & & & \\
\hline Ribosomal P, 59.7 & 0.153 & 0.155 & & & & & & & \\
\hline PCNA, 149 & $<0.001$ & $<0.001$ & 0.002 & & & & & & \\
\hline SSA/Ro5, 28.0 & 0.738 & 0.541 & 0.040 & $<0.001$ & & & & & \\
\hline SSA/Ro60, 21.4 & 0.595 & 0.517 & 0.064 & $<0.001$ & 0.733 & & & & \\
\hline SSB/La, 29.9 & 0.978 & 0.876 & 0.103 & $<0.001$ & 0.719 & 0.578 & & & \\
\hline Sm, 7.29 & $<0.001$ & $<0.001$ & $<0.001$ & $<0.001$ & $<0.001$ & $<0.001$ & $<0.001$ & & \\
\hline U1RNP, 16.0 & 0.292 & 0.211 & 0.040 & $<0.001$ & 0.381 & 0.168 & 0.192 & 0.005 & \\
\hline Sm-U1RNP, 20.8 & 0.430 & 0.326 & 0.060 & $<0.001$ & 0.638 & 0.362 & 0.395 & 0.003 & 0.860 \\
\hline
\end{tabular}

Results are shown for the percentage of levels in IC as compared to conventional measurement in sera in the upper part and as enrichment after correction for total IgG concentrations in IC and sera in the lower part. Median values for the percentage in IC as compared to that in serum and enrichment factors are presented below each autoantibody name in the upper and lower parts, respectively. Differences between individual autoantibody specificities concerning percentage in IC (upper part) and enrichment factors (lower part) were compared pairwise with the Wilcoxon signed rank test, and significant differences are depicted in italics. The corresponding distributions are shown in Fig. 1c, d. Significant $p$ values are presented in italics. Rib $P$ ribosomal $P$ 


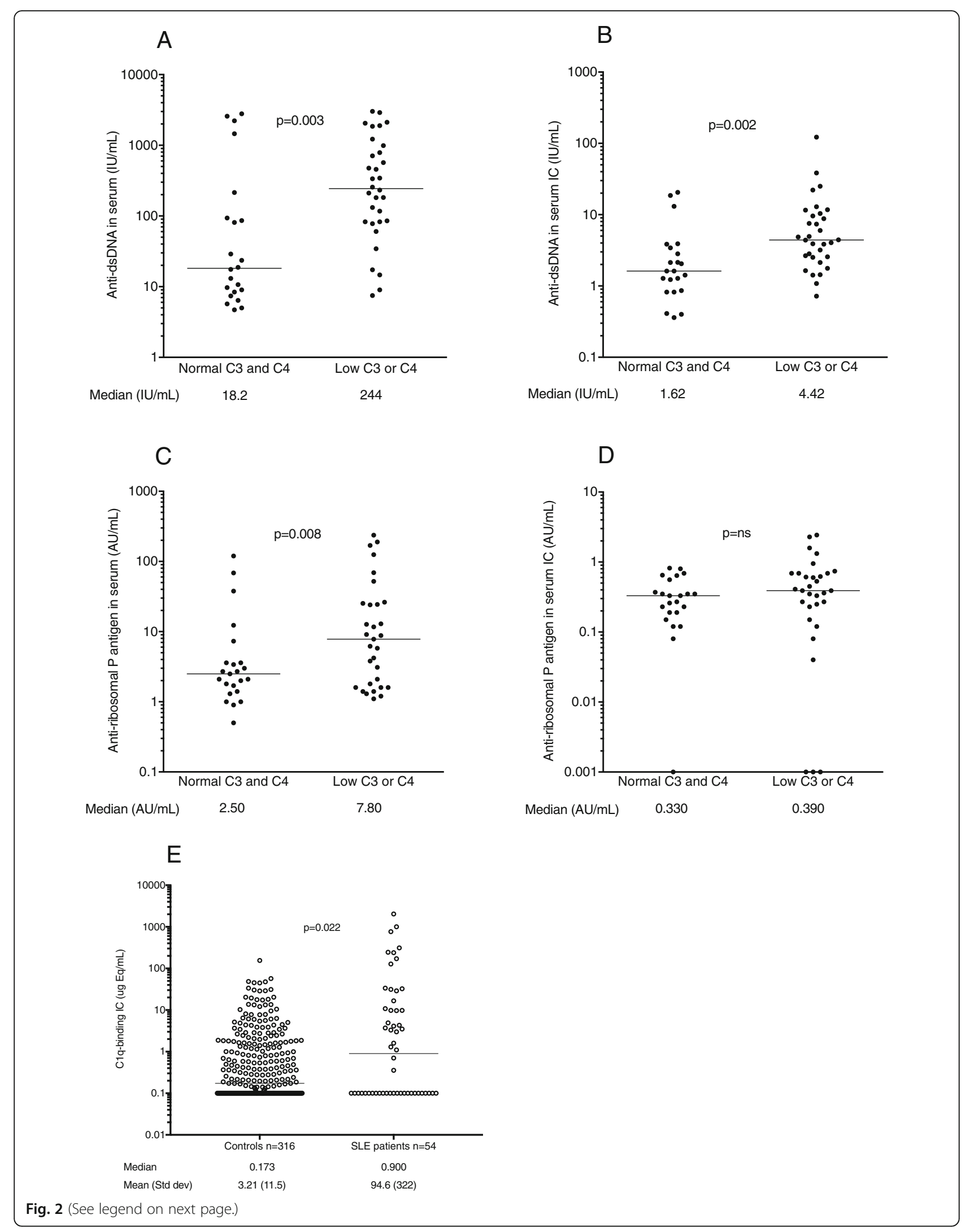


(See figure on previous page.)

Fig. 2 Associations between levels of complement protein C3 and/or C4 and levels of $\mathbf{a}, \mathbf{b}$ anti-dsDNA and $\mathbf{c}$, $\mathbf{d}$ anti-ribosomal P antigen antibodies in $\mathbf{a}$, c sera obtained with conventional measurement and $\mathbf{b}$, $\mathbf{d}$ in corresponding solubilized IC. e Levels of C1q-binding IC in 54/55 of the investigated patients, compared to a population-based non-SLE control group. Horizontal lines indicate median levels, with the corresponding figures shown below each group. ns not significant

Low levels of antibodies against the SSA/SSB complex were associated with attainment of LLDAS after 6 months of belimumab therapy, and for all these autoantibodies, the associations were stronger with IC levels than with corresponding serum levels (Fig. 4). No association with LLDAS attainment at any occasion was seen for other autoantibodies in sera or IC.

Compared to IC levels as described above, the expression of IC autoantibody levels as percentages of serum levels or as enrichment in IC in comparison to that in serum showed weaker associations to cSLEDAI-2K=0, SRI-4, or LLDAS, or no associations at all (data not shown).

\section{Changes of autoantibody levels in IC and relation to treatment response}

Serum levels of the majority of the autoantibodies were reduced already after 3 months of treatment and remained suppressed during the 2-year follow-up period. Levels of anti-dsDNA in IC showed the same pattern of a quick decline, whereas IC levels of the other autoantibodies showed a more gradual decrease, evident only after 12 or 24 months of treatment. After 2 years of follow-up, IC levels of all autoantibodies except anti-SSB and anti-ribosomal $\mathrm{P}$ were lower than in baseline sera (Table 5). The decrease in serum anti-dsDNA levels was evident both among patients reaching and not reaching cSLEDAI-2K=0 during the study period (Fig. 5a). In contrast, anti-dsDNA levels in IC decreased only among patients achieving cSLEDAI- $2 \mathrm{~K}=0$, being significant at months 3 and 24 from baseline (Fig. 5b).

\section{Discussion}

Baseline levels of anti-dsDNA in IC but not in serum were highly associated with clinical response to belimumab therapy. Low IC levels of anti-SSA/SSB associated with attainment of LLDAS, a composite tool developed to reflect a low SLE disease activity state [38, 40]. Interestingly, this association was stronger for IC levels than for the corresponding serum levels. The findings are in agreement with a recent study showing no association between serum autoantibody levels and attainment of LLDAS after belimumab therapy and collectively argue that measurement of autoantibody levels in the IC fraction of serum may better associate with clinical response to belimumab

Table 3 Correlations between levels of C 1 -binding IC on the one hand and autoantibody levels in sera or IC on the other hand

\begin{tabular}{|c|c|c|c|c|}
\hline \multirow[b]{2}{*}{ Autoantibody } & \multicolumn{2}{|c|}{ All samples $(n=54)$} & \multicolumn{2}{|c|}{ Samples with serum levels $>40 \mathrm{U} / \mathrm{mL}$ of the corresponding autoantibody } \\
\hline & Serum & IC & Serum & IC \\
\hline dsDNA & $\begin{array}{l}0.756 \\
<0.001\end{array}$ & $\begin{array}{l}0.600 \\
<0.001\end{array}$ & $\begin{array}{l}0.573 \\
<0.001\end{array}$ & $\begin{array}{l}0.490 \\
0.003\end{array}$ \\
\hline Histone & $\begin{array}{l}0.410 \\
0.002\end{array}$ & $\begin{array}{l}0.454 \\
<0.001\end{array}$ & $\begin{array}{l}0.187 \\
0.542\end{array}$ & $\begin{array}{l}0.460 \\
0.114\end{array}$ \\
\hline Ribosomal P & $\begin{array}{l}0.554 \\
<0.001\end{array}$ & $\begin{array}{l}0.290 \\
0.034\end{array}$ & $\begin{array}{l}-0.571 \\
0.139\end{array}$ & $\begin{array}{l}0.119 \\
0.779\end{array}$ \\
\hline PCNA & $\begin{array}{l}0.466 \\
<0.001\end{array}$ & $\begin{array}{l}0.170 \\
0.219\end{array}$ & NA & NA \\
\hline SSA/Ro52 & $\begin{array}{l}0.013 \\
0.928\end{array}$ & $\begin{array}{l}0.025 \\
0.858\end{array}$ & $\begin{array}{l}0.017 \\
0.942\end{array}$ & $\begin{array}{l}0.056 \\
0.809\end{array}$ \\
\hline SSA/Ro60 & $\begin{array}{l}0.055 \\
0.694\end{array}$ & $\begin{array}{l}-0.042 \\
0.765\end{array}$ & $\begin{array}{l}-0.015 \\
0.937\end{array}$ & $\begin{array}{l}-0.314 \\
0.098\end{array}$ \\
\hline $\mathrm{SSB} / \mathrm{La}$ & $\begin{array}{l}-0.039 \\
0.780\end{array}$ & $\begin{array}{l}0.096 \\
0.492\end{array}$ & $\begin{array}{l}0.291 \\
0.415\end{array}$ & $\begin{array}{l}0.380 \\
0.278\end{array}$ \\
\hline $\mathrm{Sm}$ & $\begin{array}{l}0.358 \\
0.008\end{array}$ & $\begin{array}{l}0.291 \\
0.033\end{array}$ & $\begin{array}{l}0.064 \\
0.852\end{array}$ & $\begin{array}{l}0.353 \\
0.287\end{array}$ \\
\hline U1RNP & $\begin{array}{l}0.280 \\
0.040\end{array}$ & $\begin{array}{l}0.270 \\
0.049\end{array}$ & $\begin{array}{l}-0.002 \\
0.995\end{array}$ & $\begin{array}{l}0.271 \\
0.211\end{array}$ \\
\hline Sm-U1RNP & $\begin{array}{l}0.322 \\
0.018\end{array}$ & $\begin{array}{l}0.264 \\
0.054\end{array}$ & $\begin{array}{l}0.426 \\
0.254\end{array}$ & $\begin{array}{l}0.460 \\
0.213\end{array}$ \\
\hline
\end{tabular}

Correlations and corresponding $p$ values between variables were calculated by Spearman's $\rho$. Significant correlations are presented in italics. NA not applicable (sample size $=1$ ) 
Table 4 Correlations between antibody levels in serum (upper part) and IC (lower part) vs. SLEDAl-2K in 55 belimumab-treated SLE patients

\begin{tabular}{|c|c|c|c|c|c|c|c|c|c|c|c|}
\hline & Months & dsDNA & Histone & Rib P & PCNA & SSA/Ro52 & SSA/Ro60 & SSB/La & $\mathrm{Sm}$ & $\begin{array}{l}\text { U1 } \\
\text { RNP }\end{array}$ & $\begin{array}{l}\text { Sm-U1 } \\
\text { RNP }\end{array}$ \\
\hline \multirow[t]{5}{*}{ Serum } & 0 & $\begin{array}{l}0.350 \\
(0.010)\end{array}$ & $\begin{array}{l}0.036 \\
(0.798)\end{array}$ & $\begin{array}{l}0.230 \\
(0.098)\end{array}$ & $\begin{array}{l}0.059 \\
(0.675)\end{array}$ & $\begin{array}{l}-0.086 \\
(0.541)\end{array}$ & $\begin{array}{l}-0.077 \\
(0.582)\end{array}$ & $\begin{array}{l}-0.082 \\
(0.561)\end{array}$ & $\begin{array}{l}0.272 \\
(0.049)\end{array}$ & $\begin{array}{l}0.105 \\
(0.454)\end{array}$ & $\begin{array}{l}0.235 \\
(0.091)\end{array}$ \\
\hline & $0-3$ & $\begin{array}{l}0.586 \\
(0.723)\end{array}$ & $\begin{array}{l}-0.076 \\
(0.644)\end{array}$ & $\begin{array}{l}0.223 \\
(0.173)\end{array}$ & $\begin{array}{l}0.253 \\
(0.120)\end{array}$ & $\begin{array}{l}0.156 \\
(0.344)\end{array}$ & $\begin{array}{l}0.326 \\
(0.105)\end{array}$ & $\begin{array}{l}0.210 \\
(0.200)\end{array}$ & $\begin{array}{l}0.139 \\
(0.398)\end{array}$ & $\begin{array}{l}0.264 \\
(0.104)\end{array}$ & $\begin{array}{l}0.181 \\
(0.272)\end{array}$ \\
\hline & $0-6$ & $\begin{array}{l}0.055 \\
(0.776)\end{array}$ & $\begin{array}{l}0.009 \\
(0.963)\end{array}$ & $\begin{array}{l}0.206 \\
(0.283)\end{array}$ & $\begin{array}{l}-0.253 \\
(0.204)\end{array}$ & $\begin{array}{l}-0.128 \\
(0.507)\end{array}$ & $\begin{array}{l}0.076 \\
(0.696)\end{array}$ & $\begin{array}{l}-0.175 \\
(0.364)\end{array}$ & $\begin{array}{l}0.160 \\
(0.408)\end{array}$ & $\begin{array}{l}0.003 \\
(0.987)\end{array}$ & $\begin{array}{l}0.159 \\
(0.409)\end{array}$ \\
\hline & $0-12$ & $\begin{array}{l}0.355 \\
(0.089)\end{array}$ & $\begin{array}{l}0.347 \\
(0.097)\end{array}$ & $\begin{array}{l}0.029 \\
(0.893)\end{array}$ & $\begin{array}{l}0.129 \\
(0.549)\end{array}$ & $\begin{array}{l}0.054 \\
(0.803)\end{array}$ & $\begin{array}{l}0.277 \\
(0.190)\end{array}$ & $\begin{array}{l}0.186 \\
(0.386)\end{array}$ & $\begin{array}{l}-0.009 \\
(0.968)\end{array}$ & $\begin{array}{l}-0.033 \\
(0879)\end{array}$ & $\begin{array}{l}0.071 \\
(0.742)\end{array}$ \\
\hline & $0-24$ & $\begin{array}{l}0.400 \\
(0.081)\end{array}$ & $\begin{array}{l}0.141 \\
(0.553)\end{array}$ & $\begin{array}{l}0.458 \\
(0.042)\end{array}$ & $\begin{array}{l}0.542 \\
(0.014)\end{array}$ & $\begin{array}{l}0.045 \\
(0.850)\end{array}$ & $\begin{array}{l}0.323 \\
(0.166)\end{array}$ & $\begin{array}{l}0.276 \\
(0.239)\end{array}$ & $\begin{array}{l}0.518 \\
(0.019)\end{array}$ & $\begin{array}{l}0.648 \\
(0.002)\end{array}$ & $\begin{array}{l}0.565 \\
(0.009)\end{array}$ \\
\hline \multirow[t]{5}{*}{ IC } & 0 & $\begin{array}{l}0.139 \\
(0.320)\end{array}$ & $\begin{array}{l}0.123 \\
(0.379)\end{array}$ & $\begin{array}{l}-0.087 \\
(0.535)\end{array}$ & $\begin{array}{l}-0.023 \\
(0.870)\end{array}$ & $\begin{array}{l}0.040 \\
(0.776)\end{array}$ & $\begin{array}{l}-0.042 \\
(0.765)\end{array}$ & $\begin{array}{l}0.103 \\
(0.464)\end{array}$ & $\begin{array}{l}0.194 \\
(0.164)\end{array}$ & $\begin{array}{l}0.057 \\
(0.687)\end{array}$ & $\begin{array}{l}0.129 \\
(0.358)\end{array}$ \\
\hline & $0-3$ & $\begin{array}{l}0.002 \\
(0.989)\end{array}$ & $\begin{array}{l}0.093 \\
(0.575)\end{array}$ & $\begin{array}{l}0.103 \\
(0.533)\end{array}$ & $\begin{array}{l}0.105 \\
(0.524)\end{array}$ & $\begin{array}{l}0.328 \\
(0.042)\end{array}$ & $\begin{array}{l}0.040 \\
(0.847)\end{array}$ & $\begin{array}{l}0.281 \\
(0.084)\end{array}$ & $\begin{array}{l}-0.034 \\
(0.839)\end{array}$ & $\begin{array}{l}0.056 \\
(0.734)\end{array}$ & $\begin{array}{l}0.153 \\
(0.352)\end{array}$ \\
\hline & $0-6$ & $\begin{array}{l}0.037 \\
(0.848)\end{array}$ & $\begin{array}{l}0.150 \\
(0.439)\end{array}$ & $\begin{array}{l}0.034 \\
(0.863)\end{array}$ & $\begin{array}{l}-0.235 \\
(0.238)\end{array}$ & $\begin{array}{l}0.187 \\
(0.332)\end{array}$ & $\begin{array}{l}0.135 \\
(0.485)\end{array}$ & $\begin{array}{l}0.185 \\
(0.336)\end{array}$ & $\begin{array}{l}-0.003 \\
(0.988)\end{array}$ & $\begin{array}{l}0.209 \\
(0.276)\end{array}$ & $\begin{array}{l}0.145 \\
(0.452)\end{array}$ \\
\hline & $0-12$ & $\begin{array}{l}0.389 \\
(0.060)\end{array}$ & $\begin{array}{l}0.231 \\
(0.277)\end{array}$ & $\begin{array}{l}-0.144 \\
(0.502)\end{array}$ & $\begin{array}{l}0.112 \\
(0.603)\end{array}$ & $\begin{array}{l}0.260 \\
(0.221)\end{array}$ & $\begin{array}{l}0.248 \\
(0.242)\end{array}$ & $\begin{array}{l}0.285 \\
(0.177)\end{array}$ & $\begin{array}{l}0.066 \\
(0.760)\end{array}$ & $\begin{array}{l}0.180 \\
(0.401)\end{array}$ & $\begin{array}{l}0.137 \\
(0.524)\end{array}$ \\
\hline & $0-24$ & $\begin{array}{l}0.200 \\
(0.412)\end{array}$ & $\begin{array}{l}0.071 \\
(0.774)\end{array}$ & $\begin{array}{l}-0.311 \\
(0.195)\end{array}$ & $\begin{array}{l}-0.045 \\
(0.857)\end{array}$ & $\begin{array}{l}0.058 \\
(0.813)\end{array}$ & $\begin{array}{l}0.138 \\
(0.572)\end{array}$ & $\begin{array}{l}0.126 \\
(0.608)\end{array}$ & $\begin{array}{l}0.247 \\
(0.308)\end{array}$ & $\begin{array}{l}0.128 \\
(0.602)\end{array}$ & $\begin{array}{l}0.008 \\
(0.976)\end{array}$ \\
\hline
\end{tabular}

SLEDAI-2K values including complement and centrally measured anti-dsDNA were used. In the first rows for each compartment, baseline autoantibody levels are compared with baselined SLEDAI-2K. In the following rows, changes in autoantibody levels in serum or IC during 3-, 6-, 12-, and 24-month follow-up and changes in SLEDAI-2K during the corresponding periods are compared. Spearman's $\rho$ coefficients are shown, with corresponding $p$ values within brackets. Significant correlations are depicted in italics. Rib P ribosomal P

treatment, as compared to the corresponding autoantibody levels in serum [41, 42].

Baseline serum levels of both anti-dsDNA and antiribosomal P associated with low complement levels, but levels in IC showed different associations. Whereas high baseline quantities of anti-dsDNA in IC were strongly associated with low complement levels, this was not seen for antibodies against the anti-ribosomal $\mathrm{P}$ antigen. Together, these findings imply that measurement of autoantibody levels in IC yields different associations both to SLE disease activity as to clinical response to belimumab therapy, compared to conventional measurement of autoantibody levels in serum.

Our findings are consistent with previous studies showing that patients with elevated serum anti-dsDNA levels prior to treatment initiation are expected to show a favorable response to belimumab treatment compared with placebo [27]. However, the present data suggest that levels of anti-dsDNA in IC may prove even more useful for predicting treatment outcome. This hypothesis is corroborated by the fact that diminished IC levels of anti-dsDNA were found only among patients attaining SLEDAI-2K=0 during the follow-up period.

In contrast, no association with SRI-4 was found. From a clinical point of view, however, clinical remission (here defined as cSLEDAI-2K=0) and low disease activity state (here defined as LLDAS) may be considered more relevant treatment outcomes compared with reduction of SLE activity based on SRI-4 which may be achieved despite persisting moderate/ high disease activity in patients with highly active disease at treatment initiation [43].

Median levels of anti-dsDNA in IC were $2.3 \%$ of those in serum, and the corresponding figures were $0.8-13 \%$ for the investigated autoantibody specificities, all of which were enriched in IC. The strongest associations to clinical remission, here defined as a cSLEDAI-2K score of zero attained during the follow-up period, were seen for actual levels of autoantibodies in IC. Levels expressed as percentages of serum levels with or without correction for total IgG levels weakened these associations. These other calculations were made as autoantibody quantification in IC is a new field without any previous knowledge concerning how to express data in an informative way from a clinical perspective. So far, measurement of autoantibody levels in IC without correction for levels in serum or levels of total IgG seems to be the measure most closely associated with disease activity and response to belimumab treatment in SLE patients.

It is still not clarified whether anti-dsDNA mainly deposit in target organs as monovalent antibodies or as pre-formed circulating IC. Our results argue that 


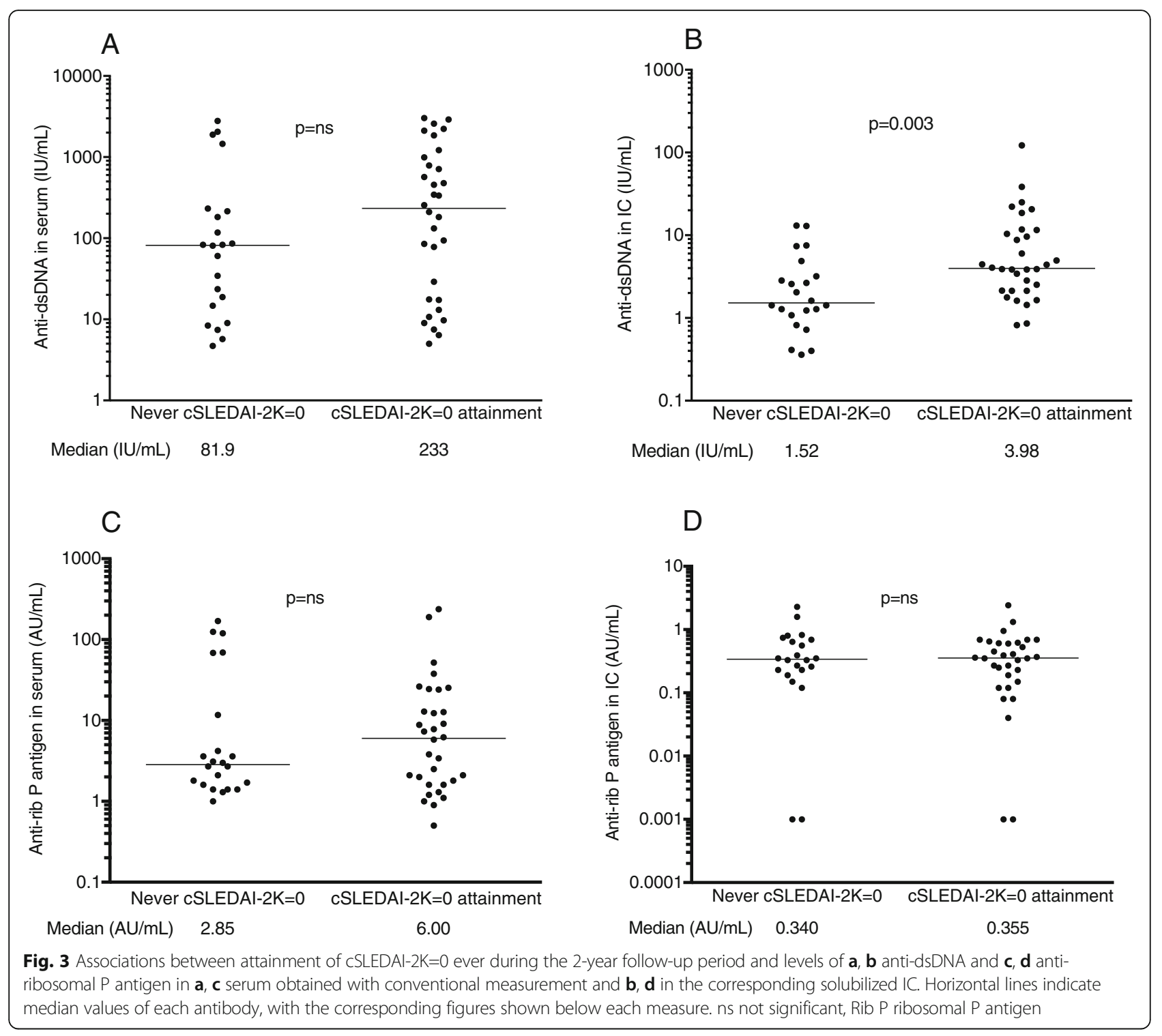

diminished passive entrapment of pre-formed circulating IC might be of importance in SLE patients who show good responses to belimumab therapy. Alternatively, the anti-dsDNA fraction detected in circulating IC might co-vary with tissue sequestration because both fractions share propensities, e.g., concerning cationic charge, but without actual sequestration of IC-bound autoantibodies. Except anti-dsDNA, autoantibodies against Sm, SSA and SSB, C1q, and C-reactive protein (CRP) have been described in glomerular immune deposits in lupus nephritis patients $[11,44]$. These results are in agreement with our finding of low LLDAS in patients with high IC levels of anti-SSA/SSB and argue that belimumab therapy may decrease the levels of different autoantibodies in circulating IC.

Previous studies on IC levels of anti-dsDNA used ultracentrifugation, a time-consuming technique that can only investigate a limited number of samples in parallel [6]. Ultracentrifugation results did not correlate with autoantibody levels in IC obtained with PEG precipitation, a commonly used IC separation technique known to also precipitate a wide array of high molecular weight proteins along with IC [45]. We believe that our new technique combines purity of obtained IC eluates with a capacity to handle large numbers of samples in clinical studies.

Early studies showed an association between persistence of circulating DNA-containing IC and increased morbidity and resistance to treatment of SLE patients. Disappearance of DNA-containing IC associated with clinical remission and improvement in glomerular filtration rate and central nervous system disease [12]. In agreement with this, we found decreased IC levels of anti-dsDNA in clinical responders to belimumab therapy, but not in non-responders. 


\section{A}

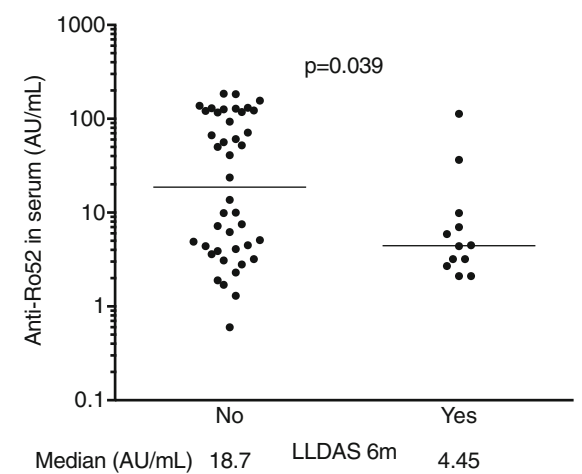

C

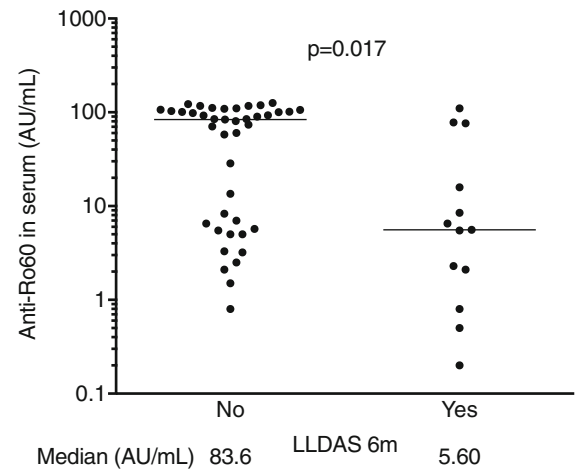

E

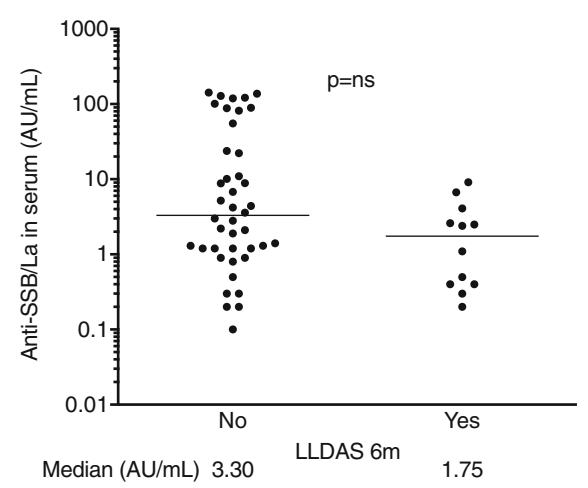

B

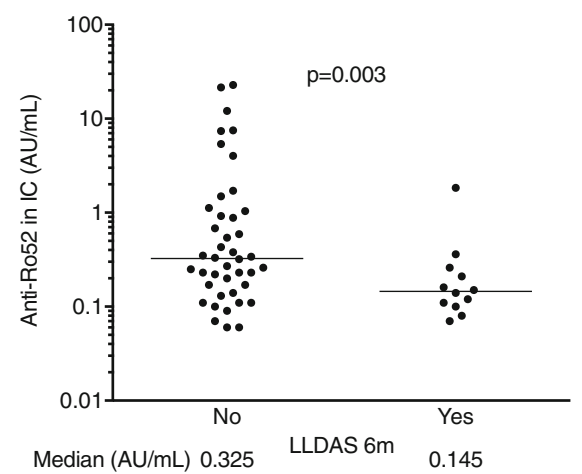

D
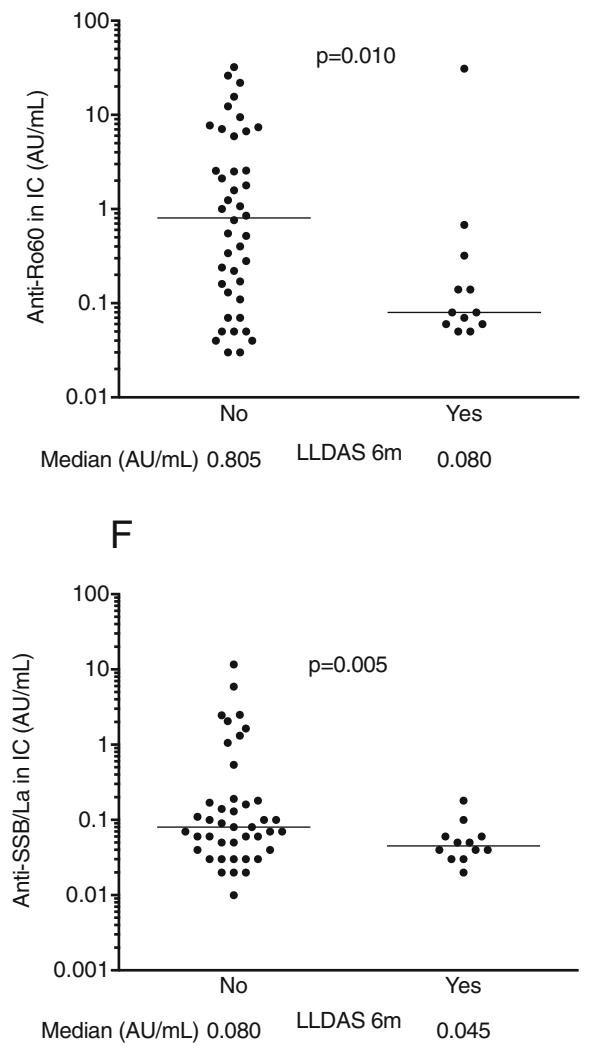

Fig. 4 Associations between attainment of LLDAS after 6 months and levels of $\mathbf{a}$, b anti-SSA/Ro52, $\mathbf{c}$, $\mathbf{d}$ anti-SSA/Ro60, and e, $\mathbf{f}$ anti-SSB/La in $\mathbf{a}, \mathbf{c}$, e sera where data were obtained with conventional measurements and $\mathbf{b}, \mathbf{d}, \mathbf{f}$ in the corresponding solubilized IC. Horizontal lines illustrate median levels, with corresponding values presented below each measure. ns not significant, LLDAS low lupus disease activity state

Only some anti-dsDNA antibodies form circulating IC. An important question to resolve is whether the fraction of anti-dsDNA participating in the formation of such circulating IC share characteristics with pathogenic anti-dsDNA, e.g., concerning the degree of cross-reactivity and cationic charge. Our technique can be used to study whether anti-dsDNA found in IC and in monovalent form in the circulation differ in such respects.
Limitations of this study include the rather low number of study subjects, and quantification of very low levels of autoantibodies in IC, below levels considered significant in serum samples. We also do not know whether certain autoantibody levels in IC should be used as thresholds for positivity. Twenty blood donors were investigated in parallel to the patients. Although these controls expressed far lower levels of antibodies both in sera and IC compared to the lupus patients they were 


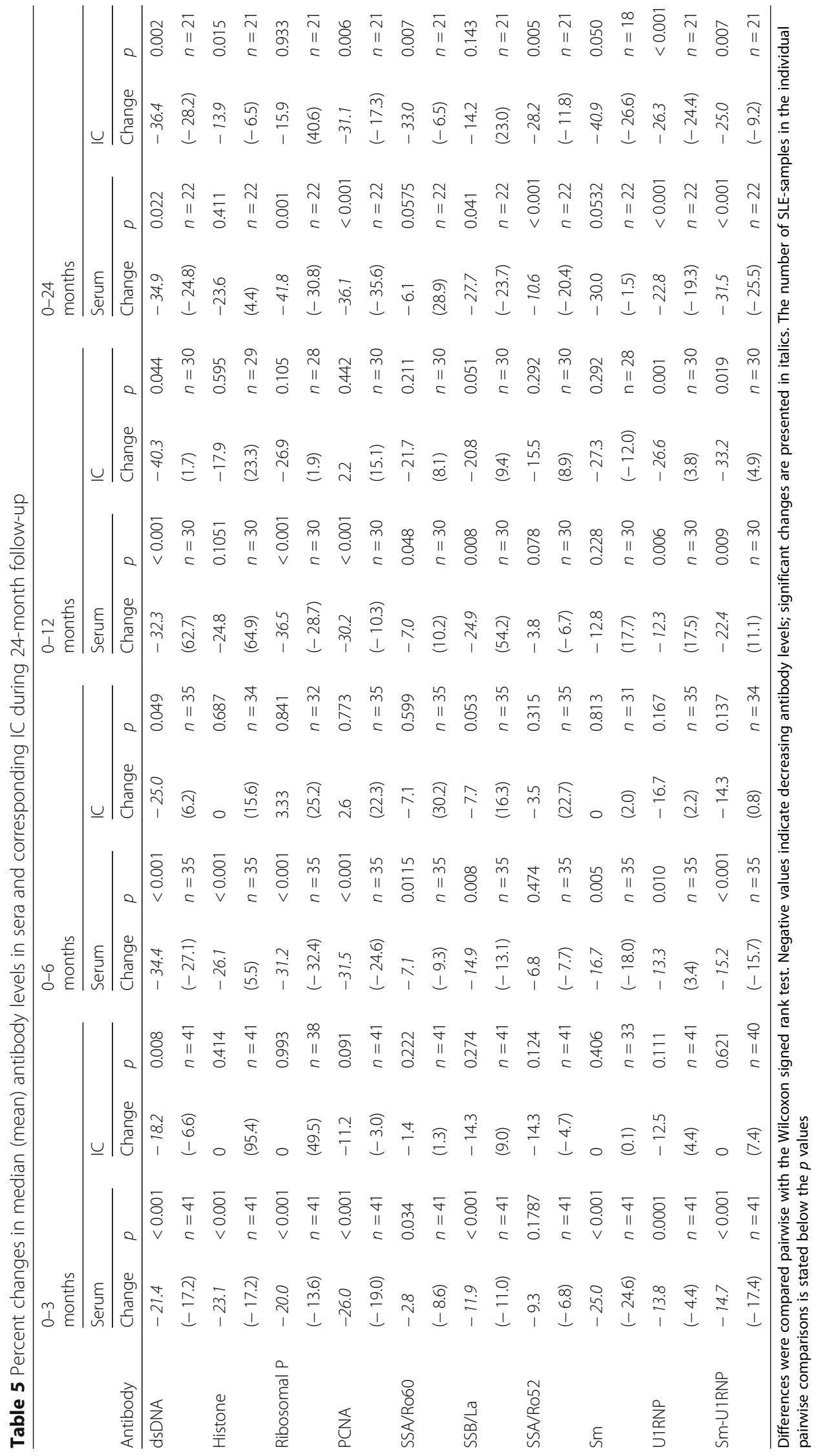




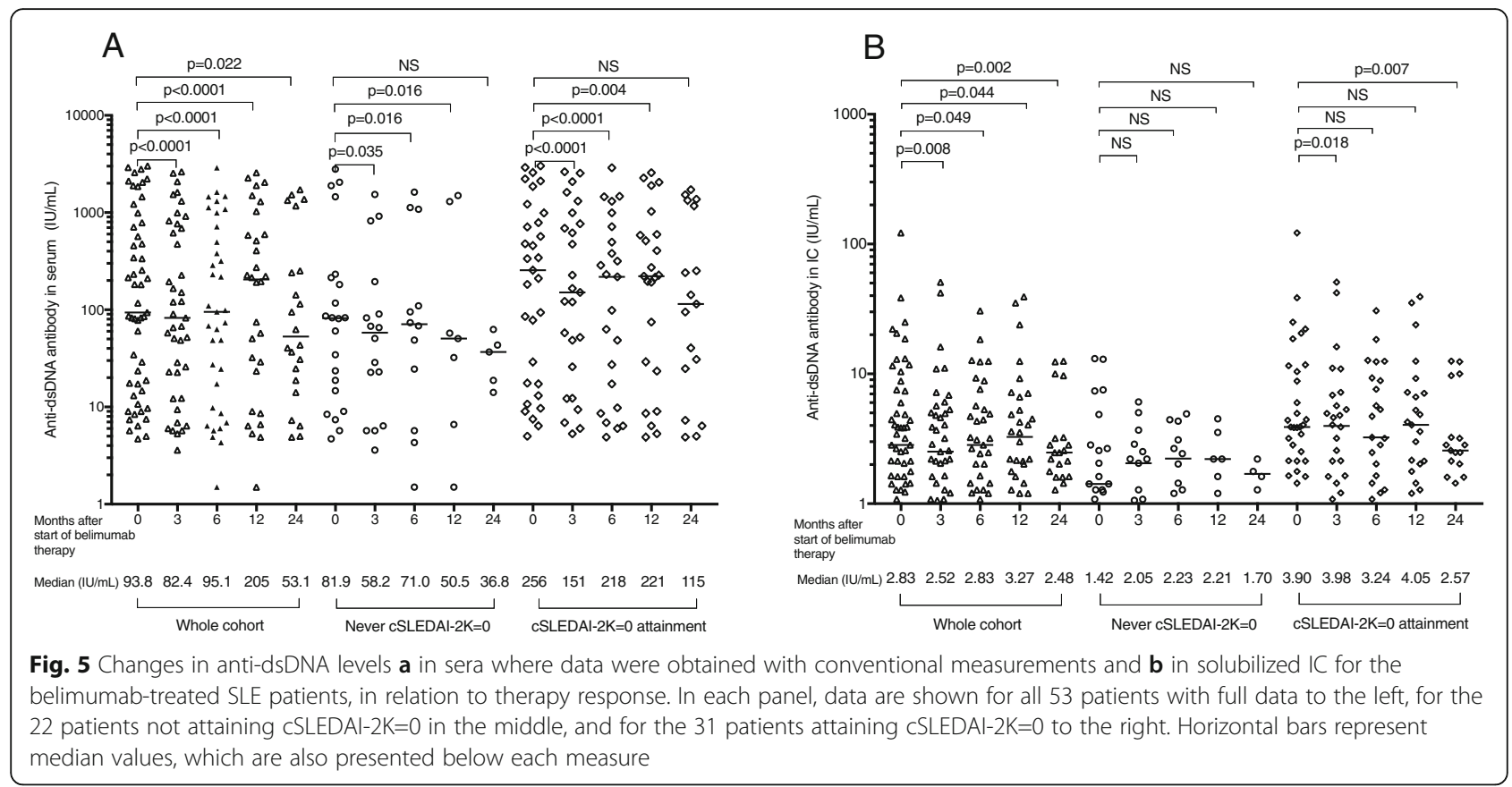

too few to establish meaningful cutoffs, and we found that evaluation of quantitative levels to be more valid in the present study.

\section{Conclusion}

By quantifying specific autoantibodies in circulating IC, we were able to demonstrate that IC levels of autoantibodies against dsDNA and the SSA/SSB complex were associated with treatment response in belimumabtreated SLE patients. We envisage that in the future, this methodology might be used to identify patients who are expected to respond to treatment with belimumab and other therapies for SLE and other IC-associated diseases, as diagnostic tools, and to characterize the unique properties of the fraction of autoantibodies that participates in the formation of circulating IC.

\section{Abbreviations}

ACPA: Anti-citrullinated peptide antibodies; ALBIA: Addressable laser bead immunoassay; ANA: Anti-nuclear antibody(ies); AU: Arbitrary unit(s); BAFF: B cell activating factor; BLyS: B lymphocyte stimulator; CIC: Circulating C1qbinding immune complex(es); CRP: C-reactive protein; CSLEDAI-2K: Clinical systemic lupus erythematosus disease activity index 2000;

DNA: Deoxyribonucleic acid; dsDNA: Double-stranded deoxyribonucleic acid; ELISA: Enzyme-linked immunosorbent assay; IC: Immune complex(es); IU: International unit(s); LLDAS: Low lupus disease activity state; PBS: Phosphate-buffered saline; PCNA: Proliferating cell nuclear antigen; Rib P: Ribosomal P antigen; RT: Room temperature; SRI-4: SLE Responder Index 4; SSA: Sjögren syndrome antigen A; SSB: Sjögren syndrome antigen B;

SLE: Systemic lupus erythematosus; SLEDAI-2K: Systemic lupus erythematosus disease activity index 2000; SLICC: Systemic Lupus International Collaborating Clinics; Sm: Smith antigen; U1RNP: U1 small nuclear ribonucleoprotein

\section{Authors' contributions}

$A S, I P, I G$, and JR conceived the study. AS developed the immune complex purification technique. AS and NCB performed laboratory analyses. IP, MF, AJ, $A Z, C S, A A B$, and IG included and performed clinical characterization of the investigated patients. AS and JR performed statistics and drafted the first version of the manuscript. All authors read, commented on, and approved the final manuscript.

\section{Funding}

This study was funded by grants from the Swedish Research Council (grant no. 521-13-3377), the Swedish Rheumatism Association (grants no. R757921 and R-844801), King Gustav V 80-year foundation (grant no. FAl-2017-0373 and FAl-2018-0504), ALF grants provided by the Uppsala County Council, Region Östergötland, the Agnes and Mac Rudberg Foundation (grant no. NA), the Ulla and Roland Gustafsson Foundation (grant no. 2019-12), Professor Nanna Svartz Foundation (grant no. 2018-00250), and the Brunnberg Foundation (grant no. NA).

\section{Availability of data and materials}

The datasets supporting the conclusions of this article are included within the article.

\section{Ethics approval and consent to participate}

Written informed consent was obtained from all study participants, except for the blood donor controls, where oral consent had been obtained. The study was performed in compliance with the Helsinki Declaration, and the study protocol was approved by the regional ethics review boards in Stockholm, Lund, Linköping, and Uppsala.

\section{Consent for publication}

NA

\section{Competing interests}

The authors declare that they have no competing interests.

\section{Author details}

'Department of Immunology, Genetics and Pathology, Uppsala University, Rudbeck Laboratory, SE-75185 Uppsala, Sweden. ${ }^{2}$ Rheumatology Unit, Department of Medicine, Karolinska Institutet, Stockholm, Sweden. ${ }^{3}$ Rheumatology, Karolinska University Hospital, Stockholm, Sweden. ${ }^{4}$ Rheumatology/AIR, Department of Clinical and Experimental Medicine, Linköping University, Linköping, Sweden. ${ }^{5}$ Section of Rheumatology, Department of Clinical Sciences, Lund University, Lund, Sweden. 
Received: 24 June 2019 Accepted: 8 November 2019

Published online: 29 November 2019

\section{References}

1. Rahman A, Isenberg DA. Systemic lupus erythematosus. N Engl J Med. 2008; 358:929-39.

2. Radic M, Herrmann M, van der Vlag J, Rekvig OP. Regulatory and pathogenetic mechanisms of autoantibodies in SLE. Autoimmunity. 2011;44: 349-56.

3. Ardoin SP, Pisetsky DS. Developments in the scientific understanding of lupus. Arthritis Res Ther. 2008;10:218.

4. Munoz LE, van Bavel C, Franz S, Berden J, Herrmann M, van der Vlag J. Apoptosis in the pathogenesis of systemic lupus erythematosus. Lupus. 2008;17:371-5.

5. Hahn BH. Antibodies to DNA. N Engl J Med. 1998;338:1359-68.

6. Bruneau C, Benveniste J. Circulating DNA:anti-DNA complexes in systemic lupus erythematosus. Detection and characterization by ultracentrifugation. J Clin Invest. 1979;64:191-8.

7. Steinman CR. Circulating DNA in systemic lupus erythematosus. Isolation and characterization. J Clin Invest. 1984;73:832-41.

8. Raz E, Brezis M, Rosenmann E, Eilat D. Anti-DNA antibodies bind directly to renal antigens and induce kidney dysfunction in the isolated perfused rat kidney. J Immunol. 1989;142:3076-82.

9. Skinner RP, Maddison PJ. Analysis of polyethylene glycol precipitates from SLE sera: antibody enrichment in association with disease activity. Clin Exp Rheumatol. 1990:8:553-60.

10. Gauthier VJ, Mannik M. A small proportion of cationic antibodies in immune complexes is sufficient to mediate their deposition in glomeruli. J Immunol. 1990;145:3348-52.

11. Mannik M, Merrill CE, Stamps LD, Wener MH. Multiple autoantibodies form the glomerular immune deposits in patients with systemic lupus erythematosus. J Rheumatol. 2003;30:1495-504.

12. Bardana EJ Jr, Harbeck RJ, Hoffman AA, Pirofsky B, Carr RI. The prognostic and therapeutic implications of DNA:anti-DNA immune complexes in systemic lupus erythematosus (SLE). Am J Med. 1975;59:515-22.

13. Smeenk R, van der Lelij G, Aarden L. Avidity of antibodies to dsDNA: comparison of IFT on Crithidia luciliae, Farr assay, and PEG assay. J Immunol. 1982;128:73-8.

14. Taki S, Hirose S, Kinoshita K, Nishimura H, Shimamura T, Hamuro J, Shirai T. Somatically mutated IgG anti-DNA antibody clonally related to germ-line encoded IgM anti-DNA antibody. Eur J Immunol. 1992;22:987-92.

15. Diamond B, Katz JB, Paul E, Aranow C, Lustgarten D, Scharff MD. The role of somatic mutation in the pathogenic anti-DNA response. Annu Rev Immunol. 1992;10:731-57.

16. Zouali M. The structure of human lupus anti-DNA antibodies. Methods (San Diego, Calif). 1997;11:27-35.

17. Waldman M, Madaio MP. Pathogenic autoantibodies in lupus nephritis. Lupus. 2005;14:19-24.

18. Berden JH. Lupus nephritis. Kidney Int. 1997;52:538-58.

19. Berden JH, Grootscholten C, Jurgen WC, van der Vlag J. Lupus nephritis: a nucleosome waste disposal defect? J Nephrol. 2002;15(Suppl 6):S1-10.

20. Chan TM, Leung JK, Ho SK, Yung S. Mesangial cell-binding anti-DNA antibodies in patients with systemic lupus erythematosus. J Am Soc Nephrol. 2002;13:1219-29.

21. Isenberg DA, Manson JJ, Ehrenstein MR, Rahman A. Fifty years of anti-ds DNA antibodies: are we approaching journey's end? Rheumatology (Oxford, England). 2007;46:1052-6.

22. Foster MH, Cizman B, Madaio MP. Nephritogenic autoantibodies in systemic lupus erythematosus: immunochemical properties, mechanisms of immune deposition, and genetic origins. Lab Invest. 1993;69:494-507.

23. Deocharan B, Qing X, Beger E, Putterman C. Antigenic triggers and molecular targets for anti-double-stranded DNA antibodies. Lupus. 2002;11:865-71.

24. O'Flynn J, Flierman R, van der Pol P, Rops A, Satchell SC, Mathieson PW, van Kooten C, van der Vlag J, Berden JH, Daha MR. Nucleosomes and C1q bound to glomerular endothelial cells serve as targets for autoantibodies and determine complement activation. Mol Immunol. 2011;49:75-83.

25. Navarra SV, Guzman RM, Gallacher AE, Hall S, Levy RA, Jimenez RE, Li EK, Thomas M, Kim HY, Leon MG, Tanasescu C, Nasonov E, Lan JL, Pineda L, Zhong ZJ, Freimuth W, Petri MA. Efficacy and safety of belimumab in patients with active systemic lupus erythematosus: a randomised, placebocontrolled, phase 3 trial. Lancet (London, England). 2011;377:721-31.
26. Furie R, Petri M, Zamani O, Cervera R, Wallace DJ, Tegzova D, SanchezGuerrero J, Schwarting A, Merrill JT, Chatham WW, Stohl W, Ginzler EM, Hough DR, Zhong ZJ, Freimuth W, van Vollenhoven RF. A phase III, randomized, placebo-controlled study of belimumab, a monoclonal antibody that inhibits B lymphocyte stimulator, in patients with systemic lupus erythematosus. Arthritis Rheum. 2011;63:3918-30.

27. van Vollenhoven RF, Petri MA, Cervera R, Roth DA, Ji BN, Kleoudis CS, Zhong ZJ, Freimuth W. Belimumab in the treatment of systemic lupus erythematosus: high disease activity predictors of response. Ann Rheum Dis. 2012;71:1343-9.

28. Wallace DJ, Stohl W, Furie RA, Lisse JR, McKay JD, Merrill JT, Petri MA, Ginzler EM, Chatham WW, McCune WJ, Fernandez V, Chevrier MR, Zhong ZJ, Freimuth WW. A phase II, randomized, double-blind, placebo-controlled, dose-ranging study of belimumab in patients with active systemic lupus erythematosus. Arthritis Rheum. 2009;61:1168-78.

29. Parodis I, Sjöwall C, Jonsen A, Ramskold D, Zickert A, Frodlund M, Sohrabian A, Arnaud L, Rönnelid J, Malmström V, Bengtsson AA, Gunnarsson I. Smoking and pre-existing organ damage reduce the efficacy of belimumab in systemic lupus erythematosus. Autoimmun Rev. 2017;16:343-51.

30. Tron F, Letarte J, Roque-Antunes Barreira MC, Lesavre P. Specific detection of circulating DNA:anti-DNA immune complexes in human systemic lupus erythematosus sera using murine monoclonal anti-DNA antibody. Clin Exp Immunol. 1982;49:481-7.

31. Mathsson L, Åhlin E, Sjöwall C, Skogh T, Rönnelid J. Cytokine induction by circulating immune complexes and signs of in-vivo complement activation in systemic lupus erythematosus are associated with the occurrence of antiSjogren's syndrome A antibodies. Clin Exp Immunol. 2007;147:513-20.

32. Åhlin E, Mathsson L, Eloranta ML, Jonsdottir T, Gunnarsson I, Rönnblom L, Rönnelid J. Autoantibodies associated with RNA are more enriched than anti-dsDNA antibodies in circulating immune complexes in SLE. Lupus. 2012;21:586-95.

33. Sohrabian A, Mathsson-Alm L, Hansson M, Knight A, Lysholm J, Cornillet M, Skriner K, Serre G, Larsson A, Weitoft T, Rönnelid J. Number of individual ACPA reactivities in synovial fluid immune complexes, but not serum antiCCP2 levels, associate with inflammation and joint destruction in rheumatoid arthritis. Ann Rheum Dis. 2018;77:1345-53.

34. Tan EM, Cohen AS, Fries JF, Masi AT, McShane DJ, Rothfield NF, Schaller JG, Talal N, Winchester RJ. The 1982 revised criteria for the classification of systemic lupus erythematosus. Arthritis Rheum. 1982;25:1271-7.

35. Petri M, Orbai AM, Alarcon GS, Gordon C, Merrill JT, Fortin PR, Bruce IN, Isenberg D, Wallace DJ, Nived O, Sturfelt G, Ramsey-Goldman R, Bae SC, Hanly JG, Sanchez-Guerrero J, Clarke A, Aranow C, Manzi S, Urowitz M, Gladman D, Kalunian K, Costner M, Werth VP, Zoma A, Bernatsky S, RuizIrastorza G, Khamashta MA, Jacobsen S, Buyon JP, Maddison P, et al. Derivation and validation of the Systemic Lupus International Collaborating Clinics classification criteria for systemic lupus erythematosus. Arthritis Rheumatism. 2012;64:2677-86.

36. Gladman DD, Ibanez D, Urowitz MB. Systemic lupus erythematosus disease activity index 2000. J Rheumatol. 2002;29:288-91.

37. Uribe AG, Vila LM, McGwin G Jr, Sanchez ML, Reveille JD, Alarcon GS. The Systemic Lupus Activity Measure-revised, the Mexican Systemic Lupus Erythematosus Disease Activity Index (SLEDAI), and a modified SLEDAI-2K are adequate instruments to measure disease activity in systemic lupus erythematosus. J Rheumatol. 2004;31:1934-40.

38. Franklyn K, Lau CS, Navarra SV, Louthrenoo W, Lateef A, Hamijoyo L, Wahono CS, Chen SL, Jin O, Morton S, Hoi A, Huq M, Nikpour M, Morand EF. Definition and initial validation of a lupus low disease activity state (LLDAS). Ann Rheum Dis. 2016;75:1615-21.

39. Mathsson L, Lampa J, Mullazehi M, Rönnelid J. Immune complexes from rheumatoid arthritis synovial fluid induce FcgammaRlla dependent and rheumatoid factor correlated production of tumour necrosis factor-alpha by peripheral blood mononuclear cells. Arthritis Res Ther. 2006;8:R64.

40. Morand EF, Trasieva T, Berglind A, Illei GG, Tummala R. Lupus low disease activity state (LLDAS) attainment discriminates responders in a systemic lupus erythematosus trial: post-hoc analysis of the phase Ilb MUSE trial of anifrolumab. Ann Rheum Dis. 2018;77:706-13.

41. Fanouriakis A, Adamichou C, Koutsoviti S, Panopoulos S, Staveri C, Klagou A, Tsalapaki C, Pantazi L, Konsta S, Mavragani CP, Dimopoulou D, Ntali S, Katsikas G, Boki KA, Vassilopoulos D, Konstantopoulou P, Liossis SN, Elezoglou A, Tektonidou M, Sidiropoulos P, Erden A, Sfikakis PP, Bertsias G, Boumpas DT. Low disease activity-irrespective of serologic status at baseline-associated with reduction of corticosteroid dose and number of 
flares in patients with systemic lupus erythematosus treated with belimumab: a real-life observational study. Semin Arthritis Rheum. 2018;48: 467-74.

42. Ramsköld D, Parodis I, Lakshmikanth T, Sippl N, Khademi M, Chen Y, Zickert A, Mikes J, Achour A, Amara K, Piehl F, Brodin P, Gunnarsson I, Malmstrom V. B cell alterations during BAFF inhibition with belimumab in SLE. EBioMedicine. 2019;40:517-27.

43. Parodis I, Emamikia S, Gomez A, Gunnarsson I, van Vollenhoven RF, Chatzidionysiou K. Clinical SLEDAI-2K zero may be a pragmatic outcome measure in SLE studies. Expert Opin Biol Ther. 2019;19:157-68.

44. Sjöwall C, Olin Al, Skogh T, Wetterö J, Morgelin M, Nived O, Sturfelt G, Bengtsson AA. C-reactive protein, immunoglobulin $\mathrm{G}$ and complement colocalize in renal immune deposits of proliferative lupus nephritis. Autoimmunity. 2013;46:205-14.

45. Robinson MW, Scott DG, Bacon PA, Walton KW, Coppock JS, Scott DL. What proteins are present in polyethylene glycol precipitates from rheumatic sera? Ann Rheum Dis. 1989;48:496-501.

\section{Publisher's Note}

Springer Nature remains neutral with regard to jurisdictional claims in published maps and institutional affiliations.

Ready to submit your research? Choose BMC and benefit from:

- fast, convenient online submission

- thorough peer review by experienced researchers in your field

- rapid publication on acceptance

- support for research data, including large and complex data types

- gold Open Access which fosters wider collaboration and increased citations

- maximum visibility for your research: over $100 \mathrm{M}$ website views per year

At BMC, research is always in progress.

Learn more biomedcentral.com/submissions 